\section{Australian Journal of \\ Crop Science}

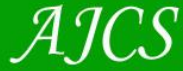

ISSN:1835-2707

AJCS 13(04):520-528 (2019)

doi: 10.21475/ajcs.19.13.04.p1383

\title{
Physiological quality and grain production of Phaseolus vulgaris (cv. BRS Pérola) using boron (B) application under irrigatation system
}

\author{
Rilner Alves Flores ${ }^{1^{*}}$, Patrícia Pinheiro da Cunha ${ }^{2}$, Virgínia Damin ${ }^{1}$, Klaus de Oliveira Abdala ${ }^{3}$, Deyvid \\ Diego Carvalho Maranhão ${ }^{4}$, Marivone Moreira dos Santos ${ }^{2}$, Luiz Raimundo Garcias Neto ${ }^{1}$, Mayara \\ Cardoso Donegá ${ }^{1}$, Raissa Alves Rodrigues ${ }^{1}$
}

\author{
${ }^{1}$ Soil Sector, Agronomy School, Federal University of Goiás, Goiânia, Brazil \\ ${ }^{2}$ Agriculture Sector, Agronomy School, Federal University of Goiás, Goiânia, Brazil \\ ${ }^{3}$ Rural Development, Agronomy School, Federal University of Goiás, Goiânia, Brazil \\ ${ }^{4}$ Department of Soil Science, Rural Federal University of Rio de Janeiro, Seropédica, Brazil
}

*Corresponding author: rilner1@hotmail.com

\begin{abstract}
Some aspects of the micronutrients management in common bean under boron fertilization in tropical agroecosystems are still poorly understood. The aim of this work was to evaluate the physiological quality and grain production of common bean using different $B$ sources and dose applications, cultivated under irrigated system. The experimental design was a randomized block, in a factorial scheme $2 \times 5 \times 3$, with two sources of B (boric acid containing 17\% of B applied in leaves and FTE (fritted trace elements) and BR-12 including $1.8 \%$ of B, applied on the soil) with five doses of each source: 0 (control), 2, 4, 6 and $8 \mathrm{~kg}^{-1}$, with three repetitions. Each plot had a total area of $5.06 \mathrm{~m}^{2}(2.25 \mathrm{~m} \times 2.25 \mathrm{~m})$. The stomatal conductance and transpiration were reduced by increasing B doses, mainly when boric acid was used. Results showed that application of boric acid at $8 \mathrm{~kg} \mathrm{ha}^{-1}$ of B reduced grain production about $21 \%$. However, application of $6 \mathrm{~kg} \mathrm{ha}^{-1}$ FTE BR 12 on the soil promoted grain production. However, application of $6 \mathrm{~kg} \mathrm{ha}^{-1}$ of B using FTE (fritted trace elements) BR-12 as a source on the soil, promoted higher production and differential profit (618 US\$ ha ${ }^{-1}$ ). Therefore, these sources and doses are recommended to common beans under irrigation systems in Brazilian Savanna agroecosystems.
\end{abstract}

Keywords: Economic viability, micronutrients, stomatal conductance, photosynthesis, plant nutrition.

Abbreviations: B_Boron; N_Nitrogen; P_Phosphorus; K_Potassium; Ca_Calcium; Mg_Magnseium; S_Sulfur; Cu_Copper; Fe_Iron; Mn_Manganese; Zn_Zinc; CEC_Cation exchange capacity; DM_Dry matter; CV_Coefficient of variation; pH_hydrogen potential.

Introduction

Brazil is the biggest producer of common bean (Phaseolus vulgaris L.) in the world, with estimated production of $1,268.9$ million tons in 2017/18 growth season, representing a decrease of $7.5 \%$ in relation to the past harvest (2016/17). The cultivated area was 1,061 million hectares in current crop, also showing a decrease of $5.5 \%$ in $2016 / 17$ season (CONAB, 2018).

Despite the significant importance of common bean in the national scenario, there are some aspects related to the productive system that could be improved, especially regarding the crop nutritional requirement and the effects of mineral sources and applied doses, aiming increase grain productivity.

Boron (B) is one of the most limiting micronutrients for plant's productivity (Wimmer and Eichert, 2013; Liu et al., 2014; Silva et al., 2016), since it is related to several physiological aspects (Marschner, 2012; Liu et al., 2014; González-Fontes et al., 2014; Flores et al., 2017). This nutrient activates several enzymes and it is a cell wall structural component. Moreover, it is associated with pectin in the middle lamella (Liu et al., 2014). In addition, B acts in the pollen germination process and pollen tube development, inactivating callose by the formation of Bcallose complexes (Prado, 2008).

Some researches correlated B level with $\mathrm{N}$ level in plant's tissues, showing a reduction in leaves and roots nitrate concentrations following $B$ reduction in plants, which affects many physiological events (Simón et al., 2013). Boron deficiency affects shoot and roots growth due to the effect on RNA metabolism, since B participates in the synthesis of the uracil, a RNA component, directly affecting protein synthesis, reducing cell division and differentiation (Mengel and Kerkby, 1982; Prado, 2008).

Boron levels in the soil vary from seven up to $85 \mathrm{mg} \mathrm{kg}^{-1}$, with average of 10 to $30 \mathrm{mg} \mathrm{kg}^{-1}$ (Malavolta, 2006; Raij, 2011) in Brazilian Savanna soils. In the soil, B can be found in silicates (borosilicates, such as tourmaline). It can be adsorbed by iron and aluminum oxides and hydroxides, where $B$ is mainly associated with organic matter (Raij, 2011). Boron occurs in the soil solution mainly as $\mathrm{H}_{3} \mathrm{BO}_{3}$, 
which is the predominant form in agricultural soils, showing $\mathrm{pH}$ ranging from 5.5 up to 6 (Malavolta, 2006). The main factor driving B behavior is soil pH (Sá and Ernani, 2016), being strongly adsorbed by $\mathrm{Fe}$ and $\mathrm{Al}$ oxides in $\mathrm{pH}$ ranging from 6 to 9 . The highest $B$ availability is observed in $\mathrm{pH}$ from 5 up to 7 (Malavolta, 2006).

Improving B management strategies is important to guarantee agricultural sustainability in the tropics, because this nutrient has a high mobility, reducing its availability in soils and increase the leaching potential, mainly in sandy soils (Raij, 2011). In a recent study, Flores et al. (2017) verified that foliar $B$ fertilization can increase productivity of common beans when used doses up to $4 \mathrm{~kg} \mathrm{ha}^{-1}$ of $\mathrm{B}$ (borax). Application of boric acid, which is a more soluble source, can decrease the productivity by $15 \%$ when it is applied at a rate of $8 \mathrm{~kg} \mathrm{ha}^{-1}$. In recent studies, Flores et al. (2018) evaluated the effect of four boron sources. They applied five $B$ rates on the soil in an irrigated system of common bean. They observed a linear increase in grain yield using $4 \mathrm{~kg} \mathrm{ha}^{-1}$ of $B$ using borax or FTE BR12, while borogran and boric acid in doses higher than $2 \mathrm{~kg} \mathrm{ha}^{-1}$ decreased grain yield.

In this sense, the development of researches aiming to investigate the $B$ dynamics in soil-plant system are still important to increase the productive efficiency, especially in irrigated systems, where B losses by leaching are usually high.

In this way, the aim of this work was to understand how B source and dose affect production and physiological quality of common bean under irrigated system and to estimate which $B$ source and dose is more profitable.

\section{Results}

\section{Relative chlorophyll index (RCI) and boron content}

The relative chlorophyll index $(\mathrm{RCl})$ was not affected by boron doses at $28\left(\mathrm{~F}=0.41^{\mathrm{ns}}\right)$ and 46 days $\left(\mathrm{F}=2.48^{\mathrm{ns}}\right)$ after seedlings emergence (DAE) (Table 1 ). Boron sources did not affect $\mathrm{RCl}$ at $28 \mathrm{DAE}\left(\mathrm{F}=0.46^{\mathrm{ns}}\right)$, which had an average of $43.91 \mu \mathrm{g} \mathrm{cm}{ }^{-2}$ (Table 1). At $46 \mathrm{DAE}$, a higher $\mathrm{RCl}$ was observed with FTE BR-12 $\left(44.37 \mu \mathrm{g} \mathrm{cm}^{-2}\right)$ application related to boric acid $\left(41.69 \mu \mathrm{g} \mathrm{cm}^{-2}\right)$. In both evaluation times (28 and $46 \mathrm{DAE}$ ) no significant interaction was observed among $B$ sources and doses (Table 1).

Boron level in plant's tissues were affected by increasing $B$ doses $(p<0.01)$ and $B$ sources $\left(F=22.12^{* *}\right)$ with no significant interaction between $B$ sources and doses. The more soluble source, boric acid, showed higher B level (180.21 mg kg ${ }^{-1}$ ) compared to FTE BR-12 source $145.16 \mathrm{mg}$ $\mathrm{kg}^{-1}$ (Table 1).

The applied B doses increased B level in leaves, using both B sources. A quadratic model could well describe the model, in which the maximum level of boric acid $322 \mathrm{mg} \mathrm{kg}^{-1}$ was observed at a rate of $8 \mathrm{~kg} \mathrm{ha}^{-1}$, while the maximum $B$ level using FTE BR-12 was $255.86 \mathrm{mg} \mathrm{kg}^{-1}$ (Fig. 1), these values were 299 and 309\%, respectively, higher than that observed in the control (without B application).

\section{Grain yield}

Boron application on soil as FTE BR-12 promoted the highest beans grain yield. It was $15.5 \%$ higher than when B was applied as boric acid in leaves (Table 1). There was an interaction effect between $B$ doses and sources (Table 1 ).

The foliar B dose as boric acid caused a linear reduction of grain yield after increasing $B$ doses application. With the application of the highest $B$ doses, grain yield was $2,877.7 \mathrm{~kg}$ $\mathrm{ha}^{-1}$, which means a reduction of $21 \%$ related to the control (Fig. 2). Application of FTE BR-12 in the soil revealed a quadratic response, with the maximum grain yield of 4.102 $\mathrm{kg} \mathrm{ha}^{-1}$, using $4.5 \mathrm{~kg} \mathrm{ha}^{-1}$ of B. It was $25.7 \%$ higher than the observed in the control (Fig. 2).

\section{Physiological parameters}

The physiological quality of beans plants was affected by $B$ application. The stomatic conductance (SC) was affected by $B$ sources, showing a higher SC after boric acid application (433.90 mmol m $\mathrm{m}^{2} \mathrm{~s}^{-1}$ ) compared with FTE BR-12 (383.73

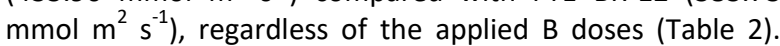
Considering the other physiological parameters, no significant differences were observed among B sources and doses, with an average of $16.34 \mu \mathrm{mol} \mathrm{m} \mathrm{s}^{-1}, 7.23 \mathrm{mmol} \mathrm{m}^{2} \mathrm{~s}$ ${ }^{1}$ and $359.23 \mathrm{ppm}$ for net photosynthesis, transpiration and $\mathrm{CO}_{2}$ internal concentration, respectively (Table 2).

Increasing $\mathrm{B}$ doses showed no significant effects on net photosynthesis and $\mathrm{CO}_{2}$ internal concentration, with average of $16.34 \mu \mathrm{mol} \mathrm{m} \mathrm{s}^{-1}$ and $359.23 \mathrm{ppm}$, respectively (Table 2). After application of increasing B doses, a linear decrease was observed in SC, with $29 \%$ reduction in the highest applied dose ( $8 \mathrm{~kg} \mathrm{ha}^{-1}$ of B as FTE BR-12) compared with the control (Fig. 3). However, when B was applied as boric acid a quadratic response was observed, with the lowest SC $\left(394.55 \mathrm{mmol} \mathrm{m}^{2} \mathrm{~s}^{-1}\right)$ being observed at a dose of $5 \mathrm{~kg} \mathrm{ha}^{-1}$ of $\mathrm{B}$, representing a $21.8 \%$ reduction related to the control, without B application (Fig. 3).

The common beans transpiration rates were not affected by $B$ doses showing an average of $7.51 \mathrm{mmol} \mathrm{m}^{2} \mathrm{~s}^{-1}$, when FTE BR-12 was applied (Fig. 4). Increasing boric acid doses caused a linear decrease in transpiration rates, with a $33.4 \%$ in this parameter compared with control, without B application (Fig. 4).

\section{Seed quality analyses in beans}

The seed germination rates were affected by B sources, with a germination rate of $99.47 \%$ and $98 \%$, when boric acid and FTE BR-12 were applied respectively, regardless of B doses (Table 3). In fact, boron doses did not affect germination rates with an average of $98.74 \%$, considering both sources (Table 3).

Using FTE BR-12 showed a higher seed electric conductivity (EC) compared with the application of boric acid, increasing the EC by $8.2 \%$, regardless $B$ doses (Table 3 ). There was an interaction between doses and sources, in which FTE increased the EC up to $10.23 \%$ with the application of 3.75 $\mathrm{kg} \mathrm{ha}^{-1}$ of B. At this rate, EC was $632.49 \mu \mathrm{S} \mathrm{cm}^{-1} \mathrm{~g}^{-1}$ (Fig. 5). Using boric acid, EC had a $6.89 \%$ reduction after application of $8 \mathrm{~kg} \mathrm{ha}^{-1}$. At this dose EC was $533.39 \mu \mathrm{S} \mathrm{cm}^{-1} \mathrm{~g}^{-1}$ (Fig. 5). In this study, application of acid boric promoted a higher seed quality, due to $E C$ reduction following the increase of $B$ doses, while the best results obtained by FTE BR-12 when doses higher or lower than $4 \mathrm{~kg} \mathrm{ha}^{-1}$ were used (Fig. 5). 
Table 1. Relative chlorophyll index (RCl), B amounts in leaves, and grain yield of Phaseolus vulgaris in function of sources and increasing boron doses.

\begin{tabular}{lcccc}
\hline Treatments & $\mathrm{RCl}^{1}$ & $\mathrm{RCl}^{2}$ & B-leaf & Grain yield \\
\hline Sources (S) & & & $\mathrm{mg} \mathrm{kg}^{-1}$ & $\mathrm{~kg} \mathrm{ha}^{-1}$ \\
Boric acid & $43.66 \mathrm{a}$ & $41.69 \mathrm{~b}$ & $180.21 \mathrm{a}$ & $3256.13 \mathrm{~b}$ \\
FTE BR 12 & $44.15 \mathrm{a}$ & $44.37 \mathrm{a}$ & $145.16 \mathrm{~b}$ & $3761.00 \mathrm{a}$ \\
$\mathrm{F}$ & $0.46^{\mathrm{ns}}$ & $6.07^{*}$ & $22.12^{* *}$ & $155.39^{* *}$ \\
\hline Rates (R) $\left(\mathrm{kg} \mathrm{ha}^{-1}\right)$ & & & & \\
0 & 43.86 & 45.90 & 65.42 & 3477.67 \\
& & & \\
2 & 44.73 & 44.45 & 109.56 & 3565.38 \\
4 & 44.00 & 40.69 & 152.54 & 3691.00 \\
6 & 43.44 & 42.22 & 188.23 & 3623.67 \\
& & & \\
8 & 43.50 & 42.32 & 297.66 & 3185.11 \\
\hline F & $0.41^{\text {ns }}$ & $2.48^{\text {ns }}$ & $112.57^{* *}$ & $18.94^{* *}$ \\
S x R & $0.78^{\text {ns }}$ & $1.18^{\text {ns }}$ & $2.83^{\text {ns }}$ & $38.87^{* *}$ \\
C.V.(\%) & 4.53 & 6.91 & 12.54 & 3.16 \\
\hline
\end{tabular}

Means followed by the same letter in the column do not differ from each other by the Tukey test at $5 \%$ probability. C.V. - Coefficient of variation. ${ }^{1}$ and ${ }^{2}$ - at 28 and 46 days after germination, respectively. ${ }^{* *},{ }^{*}$ and ${ }^{\text {ns }}$ significant at 1 and $5 \%$ and not significant at $5 \%$ of probability by the $\mathrm{F}$ test, respectively.

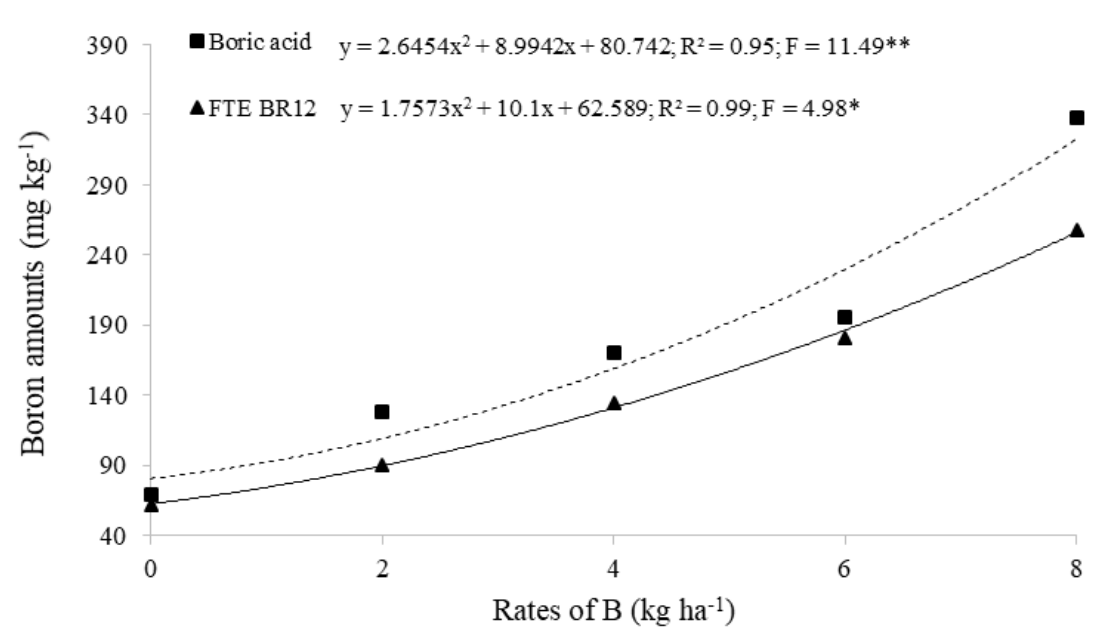

Fig 1. Boron amounts in leaves of Phaseolus vulgaris in function of sources and increasing boron doses. ** and * - significant at 1 and $5 \%$ of probability by the $\mathrm{F}$ test, respectively.

Table 2. Physiological variables of Phaseolus vulgaris in function of sources and increasing boron doses.

\begin{tabular}{|c|c|c|c|c|}
\hline Treatments & $\begin{array}{c}\text { Stomatal } \\
\text { conductance }\end{array}$ & $\begin{array}{c}\text { Liquid } \\
\text { photosynthesis }\end{array}$ & Transpiration & $\begin{array}{c}\text { Internal concentration } \\
\text { of } \mathrm{CO}_{2}\end{array}$ \\
\hline Sources (S) & $\mathrm{mmol} \mathrm{m}^{2} \mathrm{~s}^{-1}$ & $\mu \mathrm{mol} \mathrm{m} \mathrm{s}^{-1}$ & $\mathrm{mmol} \mathrm{m} \mathrm{s}^{-1}$ & $\mathrm{ppm}$ \\
\hline Boric acid & 433.90a & $17.11 \mathrm{a}$ & $6.94 a$ & $356.42 a$ \\
\hline FTE BR 12 & $383.73 b$ & $15.56 a$ & $7.51 \mathrm{a}$ & $362.04 a$ \\
\hline $\mathrm{F}$ & $16.31 * *$ & $3.52^{\mathrm{ns}}$ & $4.14^{\mathrm{ns}}$ & $0.23^{\mathrm{ns}}$ \\
\hline \multicolumn{5}{|c|}{ Rates (R) $\left(\mathrm{kg} \mathrm{ha}^{-1}\right)$} \\
\hline 0 & 469.88 & 17.00 & 8.19 & 370.07 \\
\hline 2 & 428.04 & 14.72 & 7.86 & 357.20 \\
\hline 4 & 398.98 & 15.75 & 7.22 & 360.16 \\
\hline 6 & 378.96 & 18.17 & 6.31 & 363.91 \\
\hline 8 & 368.19 & 16.04 & 6.55 & 344.83 \\
\hline $\mathrm{F}$ & $8.73 * *$ & $1.99^{\mathrm{ns}}$ & $6.58 * *$ & $0.52^{\text {ns }}$ \\
\hline$S \times R$ & $4.18^{*}$ & $2.23^{\mathrm{ns}}$ & $3.96 *$ & $1.10^{\text {ns }}$ \\
\hline C.V.(\%) & 8.32 & 13.88 & 10.72 & 8.88 \\
\hline
\end{tabular}

Means followed by the same letter in the column do not differ from each other by the Tukey test at $5 \%$ probability. C.V. - Coefficient of variation. 


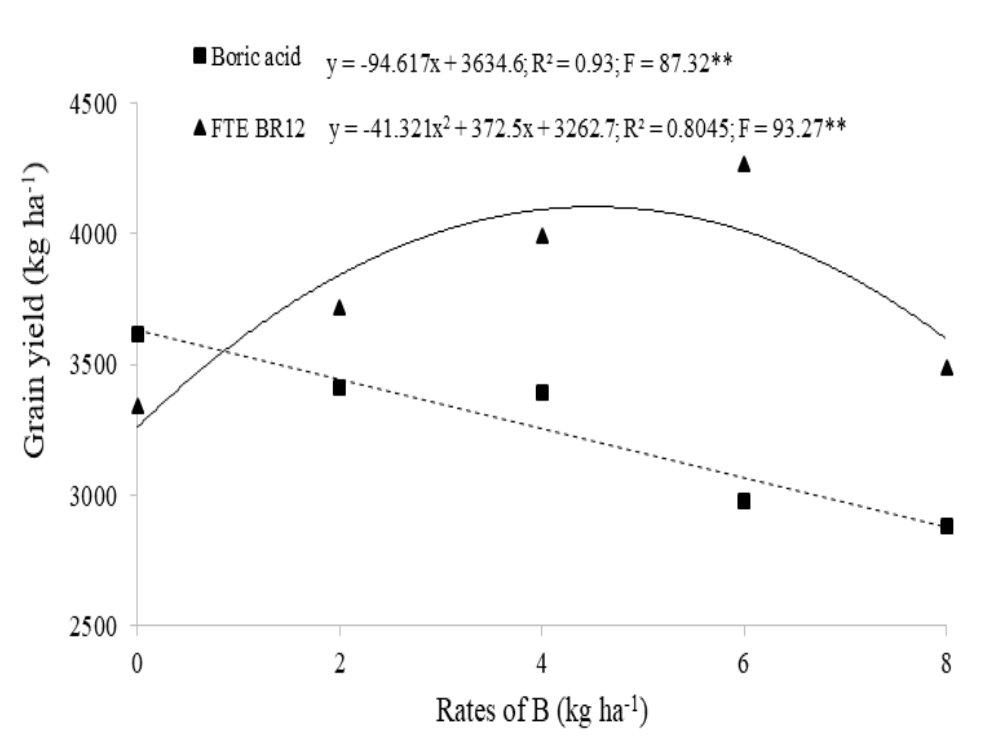

Fig 2. Grain yield of Phaseolus vulgaris in function of sources and increasing boron doses. ${ }^{*}$ and ${ }^{*}$ - significant at 1 and $5 \%$ of probability by the $\mathrm{F}$ test, respectively.

Table 3. Seed quality of Phaseolus vulgaris in function of sources and increasing boron doses.

\begin{tabular}{lcc}
\hline Treatments & Germination & Electric conductivity \\
\hline Sources (S) & $\%$ & $\mu \mathrm{cm}^{-1} \mathrm{~g}^{-1}$ \\
Boric acid & $99.47 \mathrm{a}$ & $553.40 \mathrm{~b}$ \\
FTE BR 12 & $98.00 \mathrm{~b}$ & $598.80 \mathrm{a}$ \\
F & $6.72^{*}$ & $31.13^{* *}$ \\
\hline Rates (R) $\left(\mathrm{kg} \mathrm{ha}^{-1}\right)$ & & \\
0 & 98.33 & 577.17 \\
2 & 97.67 & 575.33 \\
4 & 98.67 & 621.33 \\
6 & 99.33 & 554.67 \\
8 & 99.67 & 552.00 \\
\hline F & $1.59^{\text {ns }}$ & $9.32^{* *}$ \\
S X R & $1.31^{\text {ns }}$ & $7.98^{* *}$ \\
C.V.(\%) & 1.57 & 3.87 \\
\hline
\end{tabular}

Means followed by the same letter in the column do not differ from each other by the Tukey test at $5 \%$ probability. C.V. - Coefficient of variation. ${ }^{* *},{ }^{*}$ and ${ }^{\text {ns }}$ significant at 1 and $5 \%$ and not significant at $5 \%$ of probability by the $\mathrm{F}$ test, respectively.

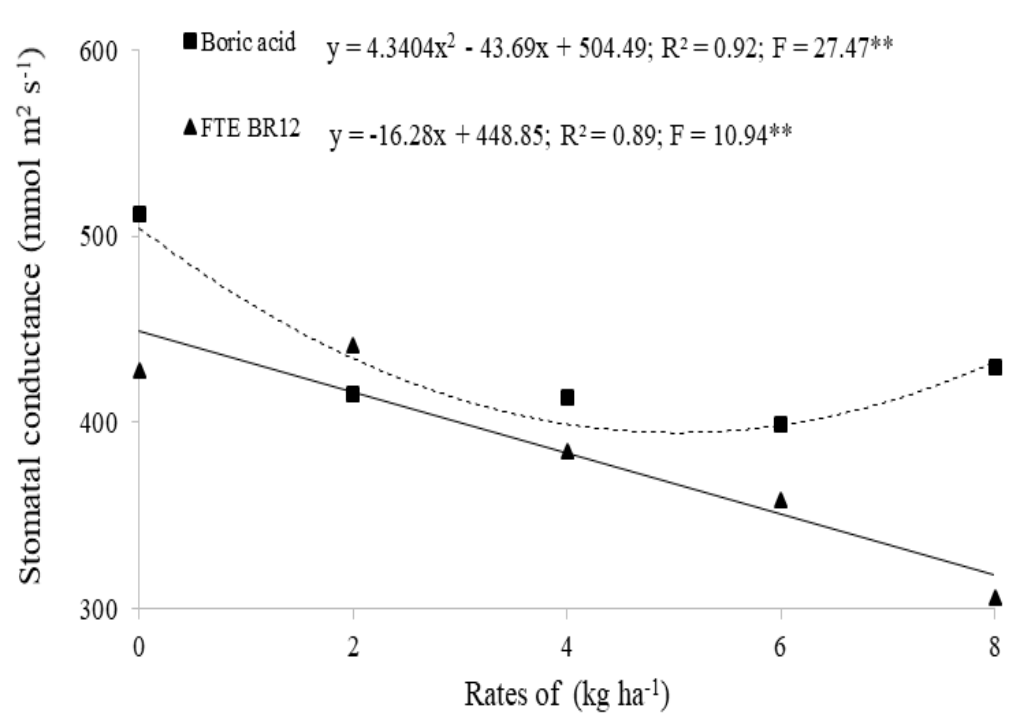

Fig 3. Stomatal conductance of Phaseolus vulgaris in function of sources and increasing boron doses. ${ }^{* *}-$ significant at $1 \%$ of probability by the $\mathrm{F}$ test. 


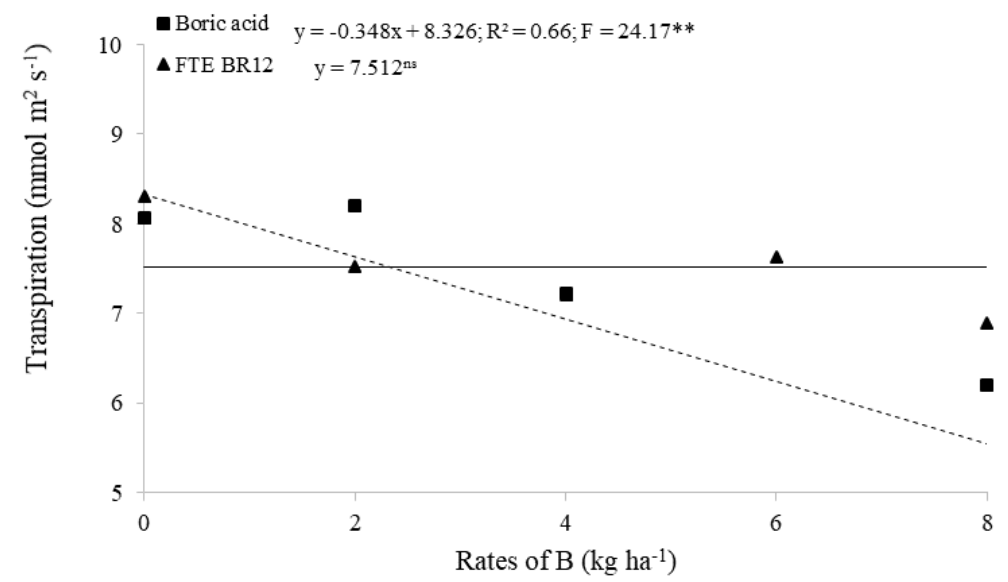

Fig 4. Transpiration of Phaseolus vulgaris in function of sources and increasing boron doses. ${ }^{\text {ns }}$ and $* *$ - not significant at $5 \%$ and significant at $1 \%$ of probability by the $F$ test, respectively.

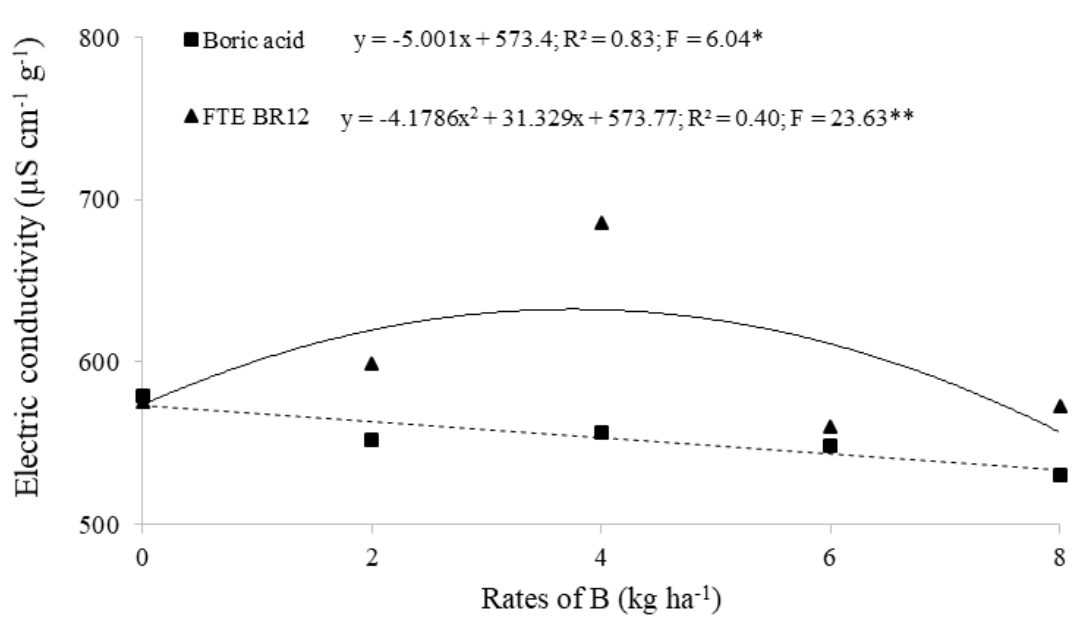

Fig 5. Electric conductivity of Phaseolus vulgaris in function of sources and increasing boron doses. ** and * - significant at 1 and $5 \%$ of probability by the $F$ test, respectively.

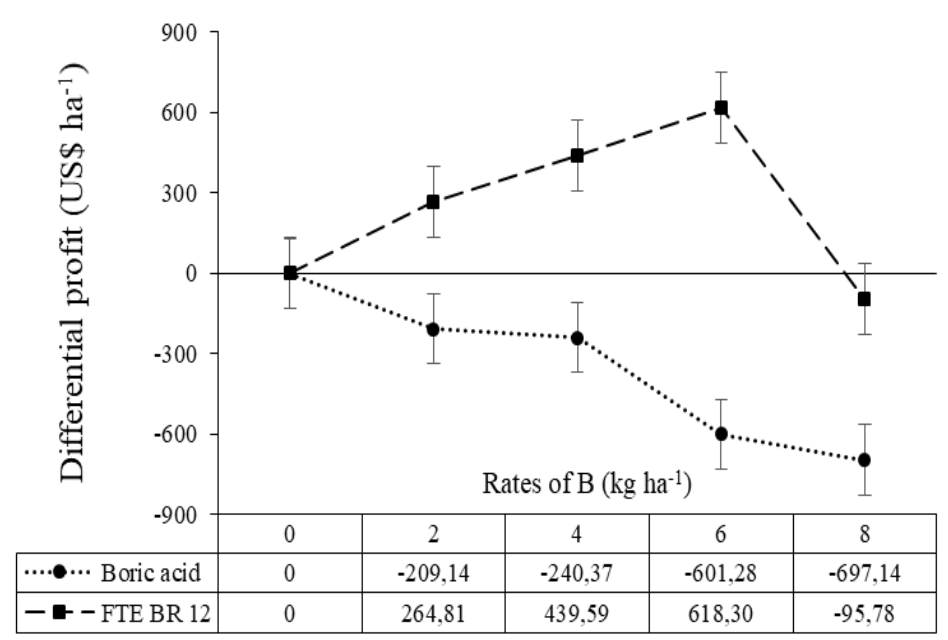

Fig 6. Differential profit of Phaseolus vulgaris in function of sources and increasing boron doses. 


\section{Economic analyses}

Using the differential profit technique we observed that boric acid application was not profitable compared with the control. In fact, boric acid application showed a negative differential profit (Fig. 6). However, using FTE BR-12 were observed positive differential profit when $B$ doses up to $6 \mathrm{~kg}$ $\mathrm{ha}^{-1}$ were applied, being this dose economically more efficient than the others (Fig. 6).

\section{Discussion}

Related results were observed by Flores et al. (2017), who observed no responses to foliar B application at 40 DAE on BRS Estilo cultivar. These authors attributed the lack of yield response to the low $B$ mobility and low $B$ levels in leaves.

The $\mathrm{RCl}$ measure the green intensity, which is related to the chlorophyll and nitrogen $(\mathrm{N}$ ) amount in plant tissues (Godoy et al., 2008). In this way, the chlorophyll readings are a nondestructive and fast method to $\mathrm{N}$ determination in plants (Maia et al., 2013). In recent studies developed by Flores et al. (2018) no increase was observed in the RCl content as a function of soil B application, like those observed in this work.

In recent researches to estimate the nitrogen sufficiency index (NSI) and the adequate $\mathrm{N}$ rates in common beans (BRS Pérola) top dressing, Silveira et al. (2017) observed a 95\% $\mathrm{NSI}$ of and they found that $1.1-1.5 \mathrm{~kg} \mathrm{ha}^{-1}$ of $\mathrm{N}$ should be applied in top dressing for each 0.1 percentage point lower than $95 \%$. On the other hand, Maia et al. (2013) found that a NSI of $90 \%$ in common bean (BRS IAC Alvorada cultivar) is more efficient to predict $\mathrm{N}$ rates in top dressing than $95 \%$.

Some researches correlated the B level with $\mathrm{N}$ level in plant tissues, showing a reduction in leaves and roots nitrate concentrations following $B$ reduction in plants, which affects many physiological events (Papadakis et al., 2004; Simón et al., 2013). Boron is related with ribonucleic acid (RNA) metabolism, since $B$ participates in uracil synthesis, which is a nitrogenous base from RNA (Prado, 2008). In that way, when $\mathrm{B}$ levels are low, there is $\mathrm{N}$ accumulation in amino acid form with a reduction of $\mathrm{N}$ protein form. It is attributed to the increase of RNAase activity, the enzyme which promotes RNA hydrolyses. Moreover, uracil synthesis is lower affecting thiamine and cytosine production (Prado, 2008).

The higher B levels were observed after boric acid application. It may be attributed to the higher B exploitation by plants, since $B$ is deposited in complexed form in wall cells (Prado, 2008), which has a higher B absorption efficiency compared to B applied on soil using FTE BR-12. That low $B$ mobility in phloem restricts the $B$ redistribution in plants (Marschner, 2012), favouring B accumulation in the diagnostic leaf ( $3 r d$ leaf with petiole in the middle third of the plants), which is used to B nutritional diagnoses (as suggested by Prado, 2008).

Flores et al. (2017) reported the same comparable results. These authors evaluated B foliar application on common beans (BRS Estilo) and they observed high B levels in leaves after boric acid application, which was attributed to the high solubility of the boric acid $\left(\mathrm{H}_{3} \mathrm{BO}_{3}\right)$ in irrigated systems, resulting in a high absorption of $B$ in leaves through the cuticle. In another study with the BRS Estilo cultivar, Flores et al. (2018) observed a linear increase in B level in leaves after application of four B sources (borogran, boric acid, borax e FTE BR12), using B doses up to $4 \mathrm{~kg} \mathrm{ha}^{-1}$ of B.

Plants treated with the highest foliar $B$ dose $\left(8 \mathrm{~kg} \mathrm{ha}^{-1}\right)$ showed visual symptoms of toxicity (necrosis and shading the edges of old leaves). The low B mobility reduces B redistribution among plant parts (Brown and Shelp, 1997; Marschner, 2012), thereby, plant's part with high transpiration rates tend to accumulate $B$ in toxic levels (Lemiska et al., 2014). Flores et al. (2017) also observed these symptoms, applying B doses of $8 \mathrm{~kg} \mathrm{ha}^{-1}$ as borax or acid boric on common beans (BRS Estilo cultivar).

Some authors suggested that foliar B application can be performed in different stages of plant's development, aiming to increase the exploitation by plants (Brown and Shelp, 1997), since B has low mobility.

Flores et al. (2017) observed a 15\% reduction in grain yield of beans (BRS Estilo cultivar) with foliar application of $8 \mathrm{~kg}$ $\mathrm{ha}^{-1}$ boric acid. The grain yield reduction promoted by boric acid suggested a toxic effect of this source, mainly when high doses are used (Prado, 2008), which can be attributed to the high solubility of this source $(17 \%)$. The high B levels in plants are usually associated with low dry mass production (Santinato et al., 2016).

Using a less soluble source, reductions in grain yield were observed only when applied doses were very high, suggesting that phytotoxic effects occur only when $B$ is in excess (Papadakis et al., 2004; Simón et al., 2013). Flores et al. (2018) did not observe the same behavior (BRS Estilo cultivar), once the crop response to borax (soluble source) and borogran (less soluble source) was linear and for boric acid (soluble source) and for FTE BR12 (less soluble source) was quadractic.

Boron is related to many physiological processes in plants, though there are many unclear functions of this nutrient. Two well-known functions of $B$ are the cell wall synthesis and the maintenance of plasmatic membrane (Prado, 2008). Plants with B deficiency can show alterations in some elements such as structural components of wall cell (pectin, hemicellulose and lignin precursors). Moreover, they can show some irregularity in deposition of cementing agent in exchange cells (Prado, 2008).

Boron participates in uracil synthesis; thereby it is related to protein and ribose syntheses, whereas this process is the most important in meristematic tissues (Prado, 2008). Moreover, the cell division and differentiation are seriously impaired when B is deficient, reducing the young plant's part growth (Mengel and Kirkby, 1987). Yamada (2000) suggested that B deficiency reduces the young roots growth, mainly new sprouts, which affect plants production, due to the low capacity to absorb nutrients and water.

Thereby, boron importance to obtain high productivity is evident, since it is well-associated to cell wall lignification, carbohydrates metabolism, sugar transportation, RNA metabolism, indoleacetic acid, phenols metabolism, respiration, $\mathrm{N}_{2}$ fixation, reduction of aluminum phytotoxicity and ascorbate metabolism (Kirkby and Römheld, 2007). Moreover, boron deficiency directly affects some physiological processes related to grain production in common beans, like the pollen grain germination, the pollen tube formation, the seeds genesis, the protein formation and the amino acids syntheses (Prado, 2008; Marschner, 2012). 
Therefore, the B imbalance in plants can cause many physiological disturbs in plants (Papadakis et al., 2004; Simón et al., 2013), which may affect crops productivity (Santinato et al., 2016).

Recent researches developed by Flores et al. (2017) using the BRS Estilo beans cultivar, also observed higher SC rates when boric acid was used compared with borax. However, the average was $276,01 \mathrm{mmol} \mathrm{m} \mathrm{s}^{-1}$, which is $37 \%$ lower than that observed in this study $\left(433.90 \mathrm{mmol} \mathrm{m}^{2} \mathrm{~s}^{-1}\right)$.

The net photosynthesis shows a directly relation with the SC (Dias and Marenco, 2007), revealing that the net photosynthesis is reduced with the decrease of SC. Comparing $B$ levels in bean after application of acid boric and FTE BR-12, we observed the relationship between these physiological parameters (Table 2).

The increase in $\mathrm{SC}$ favors the $\mathrm{CO}_{2}$ entrance in the mesophyll, with an increase in $\mathrm{CO}_{2}$ internal concentration, resulting in higher net photosynthesis rate (Taiz and Zeiger, 2013).

Photosynthesis may be affected by the increase of complex with $\mathrm{NAD}^{+}$, due to high $\mathrm{B}$ concentration in cytoplasm, which reduces the photo assimilates synthesis (Simón et al., 2013). However, in the present study no effects in net photosynthesis were observed following increases in B concentration, suggesting a minor $B$ effect in photosynthesis.

Flores et al. (2017) observed that SC in beans showed a quadratic behavior using boric acid with an increase of $13 \%$ using $3.37 \mathrm{~kg} \mathrm{ha}^{-1}$ of B. In general, the stomatal behavior can be influenced by both endogenous and environmental factors (Brodribb and Holbrook, 2003), suggesting that these factors should be observed together with nutritional factors. The $\mathrm{C} 3$ plants like common beans are more efficient in $\mathrm{CO}_{2}$ usage (Ogren, 1984), whereas they show a positive response of net photosynthesis. This fact justifies the same behavior in SC and transpiration. The decrease in these parameters after boric acid application may be associated with damages in thylakoid membrane and electrons transportation (Papadakis et al., 2004), reducing photosynthetic enzyme activity (Taiz and Zeiger, 2013) and; therefore, photo assimilates (Simón et al., 2013) and crop production.

Reis et al. (2008) evaluated the germination rates of common beans (BRS Pérola cultivar) in a Quartzipsamment soil after application of increasing $B$ doses into the soil or on plants, using borax as B source. These authors did not observe increase in the germination rates after application of $B$ doses up to $2 \mathrm{~kg} \mathrm{ha}^{-1}$. The nutrients availability for plants influences the cotyledons and embryo formation (Teixeira et al., 2005), which may affect the seed physiological quality.

Ambrosano et al. (1999) also evaluated the physiological quality of common beans (IAC-Carioca cultivar), produced in irrigated system, as a function of $B$ doses and sources. They used borogran ( $8 \%$ of B) and FTE BR-12 (1.8\% of B) and did not observe effects in germination rates after B application. The germination rate was $98.73 \%$, which was higher than the minimum required by Brazilian legislation, which is $80 \%$ (Brasil, 2009).

Lima et al. (2013) evaluated the EC and the germination rates of common bean seeds (BRS Pérola) after boric acid or borax application on soil, using doses up to $4 \mathrm{~kg} \mathrm{ha}^{-1}$. These authors observed significant effect of $B$ doses and sources. Boric acid increased germination rate $(93 \%)$, while borax showed a germination rate of $89 \%$. No significant effect was observed in the present study, while we found higher germination rates than observed by Lima et al. (2013).

Regarding EC, Lima et al. (2013) observed a quadratic response, whereas the lower EC was observed at a rate of $2.3 \mathrm{~kg} \mathrm{ha}^{-1}$ of B. Some authors suggest that high EC can be attributed to higher ions liberation in the soil following some membrane integrity damage, which means a lower seed quality (Krzyzanowski et al., 1999). Results obtained by Lima et al. (2013) showed that both B deficiency and toxicity can cause seed damages.

Flores et al. (2017) used BRS Estilo cultivar in irrigated system and observed that applying the less soluble source borax up to $4 \mathrm{~kg} \mathrm{ha}^{-1}$ of $\mathrm{B}$ was more profitable than boric acid application. In another work, Flores et al. (2018) observed a similar behavior of $B$ sources with applied soil doses up to $2 \mathrm{~kg} \mathrm{ha}^{-1}$ de $B$. The $B$ increase in the soil was higher when borax was used as a B source. It promoted a higher differential profit as well, which was 781 dollars, following by FTE BR12 (235 dollars). However, boric acid and borogran, promoted a negative differential profit of 229 and 614 dollars, respectively, when applied in the soil at a rate of $4 \mathrm{~kg} \mathrm{ha}^{-1}$ of $\mathrm{B}$.

Richetti and Melo (2013) showed that $23 \%$ of the total production costs are expenses with fertilizers, being micronutrients responsible for $0.5 \%$ of this cost. In that way, the results presented in this study suggested that FTE BR12 source is a more rentable B source, being the choice socially adequate (Thomas and Callan, 2010), since it guarantee better profitability to the farmer, which can result in benefits to the society, since it may increase food supply associated with a lower environmental impact.

\section{Materials and methods}

\section{Experimental area}

An experiment was carried out at Federal University of Goiás, Goiânia, Brazil ( $16^{\circ} 35^{\prime \prime}$ latitude south and $49^{\circ} 21^{\prime}$ longitude west, at approximately $730 \mathrm{~m}$ of altitude and $1,600 \mathrm{~mm}$ average annual rainfall), in an area with central pivot irrigation system. The climate is Aw (mega thermal) or tropical savannah, with dry winters and rainy summers, according to Köppen classification. Soil was classified as Rhodic Hapludox (Soil Taxonomy, 2014).

The soil analysis showed the following properties: $\mathrm{pH}=5.1$; Organic matter $=29 \mathrm{~g} \mathrm{dm}^{-3} ; \mathrm{P}=6.7 \mathrm{mg} \mathrm{dm}^{-3} ; \mathrm{K}=0.52 \mathrm{cmol}_{\mathrm{c}}$ $\mathrm{dm}^{-3} ; \mathrm{Ca}=1.7 \mathrm{mmol}_{\mathrm{c}} \mathrm{dm}^{-3} ; \mathrm{Mg}=0.6 \mathrm{mmol}_{\mathrm{c}} \mathrm{dm}^{-3} ; \mathrm{S}=1.2 \mathrm{mg}$ $\mathrm{dm}^{-3} ; \mathrm{B}=0.19 \mathrm{mg} \mathrm{dm}^{-3} ; \mathrm{Cu}=2.8 \mathrm{mg} \mathrm{dm}^{-3} ; \mathrm{Fe}=82 \mathrm{mg} \mathrm{dm}^{-3} ;$ $\mathrm{Mn}=44 \mathrm{mg} \mathrm{dm}^{-3} ; \mathrm{Zn}=4.6 \mathrm{mg} \mathrm{dm}^{-3} ; \mathrm{H}+\mathrm{Al}=2.4 \mathrm{mmol}_{\mathrm{c}} \mathrm{dm}^{-3} ;$ $\mathrm{CEC}=52.2 \mathrm{mmol}_{\mathrm{c}} \mathrm{dm}^{-3}$; Base saturation $(\%)=54 \%$, with 470 $\mathrm{g} \mathrm{kg}^{-1}$ of clay.

\section{Experimental design}

The experimental design was a randomized block, in a factorial scheme $2 \times 5 \times 3$, with two sources of B (boric acid with $17 \%$ of $B$ applied on common beans leaves 40 days after sowing and FTE (fritted trace elements) BR-12 with $1.8 \%$ of $B$ applied in the soil at sowing) and five doses: 0 (control), 2, 4, 6 and $8 \mathrm{~kg} \mathrm{ha}^{-1}$ with three repetitions. Each plot had a total area of $5.06 \mathrm{~m}^{2}(2.25 \mathrm{~m} \times 2.25 \mathrm{~m})$. 


\section{Experiment development}

Prior to sowing, lime application was performed at $310 \mathrm{~kg}$ $\mathrm{ha}^{-1}$ (92\% of total power neutralization), and the application amount was determined by the base saturation method (Troeh and Thompson, 1993), with the aim of increase bases saturation to $65 \%$. A conventional tillage system was conducted. The common beans cultivar BRS Pérola was chosen for the experiment. This is a cultivar with Carioca grain, suitable for cultivation in 12 states in the five macroregions of Brazil, with indeterminate growth habit, between types II and III, cycle between 85 and 95 days, and 100 seeds weight of $27 \mathrm{~g}$.

Seeds were sown in rows, with each plot having five lines spaced $0.45 \mathrm{~m}$ apart with a plant density of 17 plants per linear meter. On the same day, $20 \mathrm{~kg} \mathrm{ha}^{-1}$ of $\mathrm{N}, 110 \mathrm{~kg}$ of $\mathrm{P}_{2} \mathrm{O}_{5}$ and $70 \mathrm{~kg} \mathrm{ha}^{-1}$ of $\mathrm{K}_{2} \mathrm{O}$ were applied using the following fertilizer: urea, single superphosphate and potassium chlorate, respectively. Topdressing nitrogen fertilization was performed at 20 and 40 days after germination (DAG), using urea at 80 and $40 \mathrm{~kg} \mathrm{ha}^{-1}$ of $\mathrm{N}$, respectively.

\section{Physiological parameters}

The physiological parameters measured were: transpiration rate (T) $\left(\mathrm{mmol} \mathrm{m}^{2} \mathrm{~s}^{-1}\right)$, stomatal conductance (Gs) $\left(\mathrm{mmol} \mathrm{m}{ }^{2}\right.$ $\left.\mathrm{s}^{-1}\right), \mathrm{CO}_{2}$ internal concentration (Ci) (ppm) and net photosynthesis $\left(\mu \mathrm{mol} \mathrm{m} \mathrm{m}^{2} \mathrm{~s}^{-1}\right)$. These measurements were taken at R5 stage (between pre-flowering and pods formation), using an Infrared Gas Analyzer (IRGA, Li-COR, Lincoln, USA). Inside the plot, plants were chosen in a randomized pattern, and the first completely expanded leaf from the apex of the main stem was used. The measurements were performed between 9:00 $\mathrm{h}$ and 14:00 h.

The relative chlorophyll index $(\mathrm{RCl})$ was determined at 28 and at 46 DAG as indicated by Barbosa Filho et al. (2008) using a chlorophyll meter, model FALKER $^{\circledR}$, ClorofiLOG CFL1030. The equipment uses photodiodes emitting at three wavelengths: two emit within the red band, close to the peaks of each type of chlorophyll $(\lambda=635$ and $660 \mathrm{~nm})$ and one in the near infrared $(\lambda=880 \mathrm{~nm})$. In this way, a minor sensor receives the radiation transmitted through the leaf structure. Using this data, the equipment provides the relative indexes of chlorophyll. In each plot, plants were taken in a randomized pattern, and the first completely expanded leaf from the apex of the main stem was used.

In each plot, $2 \mathrm{~m}$ of the three central lines were harvested in 7th of October 2015. The plant's material was weighed and sub-sampled to determine grain yield $\left(\mathrm{kg} \mathrm{ha}^{-1}\right)$. Grain quality was evaluated by germination rate and electrical conductivity (EC). Germination rates was evaluated using the germitest paper roll, at $25{ }^{\circ} \mathrm{C}$ of temperature, with four replicates containing 50 seeds each (Brasil, 2009). The EC evaluation was performed with four replicates containing 50,75 and 100 seeds each, following methodology proposed by Brasil (2009).

\section{Plant analysis}

The foliar B level was evaluated in the pre-flowering stage. Samples were taken from 20 plants in each plot, using the diagnostic leaves (first leaf completely expanded). The boron analyses were performed using the dry digestion method with the use of a muffle furnace and $B$ determination was performed using azomethine- $\mathrm{H}$ by a spectrophotometric method (Silva, 2009).

\section{Economic analysis}

The economic analysis was done using the partial budget technique (Noronha, 1987). The differential profit was calculated using the budget costs and the differential income, using the control treatment as a reference. Grain productivity was used to calculate the productivity gain in $\mathrm{B}$ treatments related to the control (PG). The production value $(P V)$ was obtained by the following equation:

$P V=P G * P$

Where:

$\mathrm{P}=$ product price in Brazil. The average price deflated of the US\$ $\mathrm{kg}^{-1} 0.81$ (Agrolink, 2016) was used. This value was calculated using data of price from the last 15 years (2001 up to 2016).

The differential profit was obtained by the following equation:

$P d=I d-C d$

Were:

$\mathrm{Pd}=$ differential profit

$\mathrm{Id}=$ differential Income $=\mathrm{It} \mathbf{i}-\mathrm{It}_{0}$

$\mathrm{Cd}=$ differential cost $=\mathrm{Cti}-\mathrm{Ct}_{0}$

$\mathrm{ti}=$ Treatment $\mathrm{i}$

$\mathrm{t}_{0}=$ Control

\section{Statistical analyses}

The statistical analyses were performed in a factorial scheme with two factors: B sources and B doses. When significant interaction between the factors was observed, the interactions were partitioned and the separated effect of each factor was not considered. Using the Sisvar program, the effect of B source was evaluated using the Tukey's test $(p \leq 0.05)$ and the B effect doses was described using a regression analysis. The parameters used to choose the regression model were the $\mathrm{F}$ test significance, predicted and adjusted $R^{2}$ and the residual plots independence (including Durbin-Watson test to verify correlation between adjacent residuals.

\section{Conclusion}

The physiological quality of common bean is slightly affected by $B$ sources and doses. Only stomatal conductance and transpiration were reduced by increasing $B$ doses application, mainly when boric acid was used. Boron application of $8 \mathrm{~kg} \mathrm{ha}^{-1}$ as boric acid reduced grain production by $21 \%$ with no economic justification. However, FTE BR-12 applied in soil promoted grain production, being 6 $\mathrm{kg} \mathrm{ha}^{-1}$ economic and more efficient than the others.

\section{Acknowledgments}

The authors would like to thank and acknowledge FAPEG for the scholarship awarded for the development of this study. 


\section{References}

Agrolink (2016) Quotation history. [cited 2016 july 4]; Available from: http://www.agrolink.com.br/cotacoes/historico/go/feijaocarioca-sc-60kg.

Ambrosano EJ, Ambrosano GMB, Wutke EB, Bulisani EA, Martins ALM, Silveira LCP (1999) Effects of nitrogen fertilization and micronutrients as seed of common bean cultivar IAC-Carioca. Bragantia. 58:393-399.

Barbosa Filho MP, Cobucci T, Fageria NK, Mendes PN (2008) Topdressing nitrogen fertilizer requirements determination for irrigated common bean, by leaf portable chlorophyll meter. Cienc Rural. 38:1843-1848.

Brasil. Ministério da agricultura, pecuária e abastecimento (2009) Regras para análise de sementes. MAPA, Brasília.

Brodribb TJ, Holbrook NM (2003) Stomatal closure during leaf dehydration, correlation with other leaf physiological traits. Plant Physiology. 132:2166-2173.

Brown PH, Shelp BJ (1997) Boron mobility in plants. Plant Soil. 193:85-101.

Companhia Nacional de Abastecimento - CONAB (2018) abril 7. Acompanhamento de safra brasileira: grãos, safra 2017/18, 7 ํㅜ levantamento. CONAB, Brasília.

Dias DP, Marenco RA (2007) Fotossíntese e fotoinibição em mogno e acariquara em função da luminosidade e temperatura foliar. Pesq Agropec Bras. 42:305-311.

Flores RA, Rodrigues RA, Cunha PP, Damin V, Arruda EM, Abdala KO, Donegá MC (2018) Grain yield of Phaseolus vulgaris in a function of application of boron in soil. J Soil Sci Plant Nut. 18(1):144-156.

Flores RA, Silva RG, Cunha PP, Damin V, Abdala KO, Arruda EM, Rodrigues RA, Maranhão DDC (2017) Economic viability of Phaseolus vulgaris (BRS Estilo) production in irrigated system in a function of application of leaf boron. Acta Agric Scand B. 67:1-8.

Godoy LV, Santos TS, Villas Bôas RL, Leite Júnior JB (2008) Relative chlorophyll index and nitrogen status of fertigated coffee plants during the crop season. Rev Bras Cienc Solo. 32:217-226.

González-Fontes A, Navarro-Gochicoa MT, Camacho-Cristóbal JJ, Herrera-Rodríguez MB, Quiles-Pando C, Rexach J (2014) Is $\mathrm{Ca}^{2+}$ involved in the signal transduction pathway of boron deficiency? New hypotheses for sensing boron deprivation. Plant Sci. 217218:135-139.

Kirkby EA, Römheld V (2007) Micronutrientes na fisiologia de plantas: funções, absorção e mobilidade. Tradução: Ferreira, S.O., translator; Encarte Técnico. Informações Agronômicas. 118.

Krzyzanowski FC, Vieira RD, França Neto JB (1999) Vigor de sementes: conceitos e testes. Londrina: ABRATES.

Lemiska A, Pauletti V, Cuquel FL, Zawadneak MAC (2014) Production and fruit quality of strawberry under boron influence. Cienc Rural. 44:622-628.

Lima ML, Cardoso FR, Galante AHA, Teixeira GCS, Teixeira IR, Alves SMF (2013) Fontes e doses de boro na qualidade de sementes de feijão-comum e mamona sob consórcio. Rev Caatinga. 26:31-38.

Liu G, Dong X, Liu L, Wu L, Peng S, Jiang C (2014) Boron deficiency is correlated with changes in cell wall structure that lead to growth defects in the leaves of navel orange plants. Sci Hortic. 176:54-62.

Maia SCM, Soratto RP, Biazotto FO, Almeida AQ (2013) Estimativa da necessidade de nitrogênio em cobertura no feijoeiro IAC Alvorada com clorofilômetro portátil. Semina: Ciênc Agrár. 34:2229-2238

Malavolta E (2006) Manual de nutrição mineral de plantas. São Paulo: Editora Agronômica Ceres.
Marschner H (2012) Mineral nutrition of higher plants. Ed. London, Academic Press.

Mengel K, Kirkby EA (1987) Principles of plant nutrition Worblaufen-Bern: International Potash Institute.

Noronha JF (1987) Projetos agropecuários \& administração financeira: orçamento e viabilidade econômica. Editora São Paulo: ATLAS. Ogren WL (1984) Photorespiration: pathways, regulation, and modification. Annu Rev Plant Biol. 35:415-442.

Papadakis IE, Dimassi KN, Bosabalidis AM, Therios I, Patakas A Giannkoula A (2004) Effects of B excesso on some physiological and anatomical parameters of "Navelina" orange plants grafted on two rootstocks. Environ Exp Bot. 51:247-257.

Prado RM (2008) Nutrição de Plantas. São Paulo: Editora UNESP.

Raij B (2011) Fertilidade do solo e manejo de nutrientes. Piracicaba: IPNI.

Reis CJ, Soratto RP, Biscaro GA, Kulczynski SM, Fernandes DS (2008) Doses e modos de aplicação de boro na produção e qualidade fisiológica de sementes de feijão em solo de Cerrado. Rev Ceres. 55:258-264

Richetti A, Melo CLP (2013) Viabilidade econômica da cultura do feijão comum, safra da seca de 2014, em Mato Grosso do Sul. Embrapa, Dourados.

Sá AA, Ernani PR (2016) Boron Leaching Decreases with Increases on Soil pH. Rev Bras Cienc Solo. 40: e0150008

Santinato F, Tavares TO, Prado RM, Caione G, Silva VA, Santinato R (2016). Boron doses applied to soil during coffee development. Comunicata Scientiae. 7:49-55

Silva FC (2009) Manual de análises químicas de solos, plantas e fertilizantes. 2th ed. Brasília: Embrapa Informação Tecnológica.

Silva GP, Prado RM, Silva Júnior GB, Silva SLO, Leal FT, Costa LC, Carmona VMV (2016) Broccoli growth and nutritional status as influenced by doses of nitrogen and boron. Afr J Agric Res. 11:1858-1861

Silveira PM, Gonzaga ACO (2017) Portable chlorophyll meter can estimate the nitrogen sufficiency index and levels of topdressing nitrogen in common bean. Pesqui Agropec Trop. 47:1-6.

Simón I, Díaz-López L, Gimeno V, Nieves M, Pereira WE, Martínez V, Lidon V, García-Sánchez F (2013) Effects of boron excess in nutrient solution on growth, mineral nutrition, and physiological parameters of Jatropha curcas seedlings. J Plant Nutr Soil Sci. 176:165-174.

Soil Taxonomy - soil survey staff. (2014) Keys to soil taxonomy. 12th ed. United States Department of Agriculture Natural Resources Conservation Service, Washington, DC, USA.

Taiz L, Zeiger E (2013) Fisiologia vegetal. 5th Ed. Porto Alegre: Artmed.

Teixeira IR, Borém A, Araújo GAA, Andrade MJB (2005) Teores de nutrientes e qualidade fisiológica de sementes de feijão em resposta à adubação foliar com manganês e zinco. Bragantia. 64:83-88.

Thomas JM, Callan SJ (2010) Economia ambiental: fundamentos, políticas e aplicações. 4th ed, Cengage Learning, São Paulo.

Troeh FR, Thompson LM (1993) Soil and soil fertility. 5th ed. New York. Oxford University Press.

Wimmer MA, Eichert T (2013) Review: Mechanisms for boron deficiency-mediated changes in plant water relations. Plant Sci. 203-204:25-32.

Yamada T (2000). Boro: será que estamos aplicando a dose suficiente para o adequado desenvolvimento das plantas? Informações Agronômicas. 90. 